\title{
MEMAHAMI DINAMIKA PSIKOLOGIS INDIVIDU YANG TURUT TERLIBAT DALAM KERUSUHAN MASSA MEI 1998: SEBUAH KERANGKA PSIKOLOGIS
}

\author{
Eunike Mutiara Himawan ${ }^{1,3}$, Annie Pohlman ${ }^{1}, \&$ Winnifred Louis ${ }^{2}$ \\ ${ }^{1}$ School of Languages and Cultures, The University of Queensland, St. Lucia QLD 4072, Australia \\ ${ }^{2}$ School of Psychology, The University of Queensland, St. Lucia QLD 4072, Australia \\ ${ }^{3}$ Faculty of Psychology, Universitas Pelita Harapan, Jln. M H Thamrin Boulevard 1100, Lippo Village, Tangerang, Indonesia
}

Korespondensi:e.mutiara@uq.net.au

\section{UNDERSTANDING THE PSYCHOLOGICAL DYNAMICS OF INDIVIDUALS INVOLVED IN THE MAY 1998 MASS RIOTS: A PSYCHOLOGICAL FRAMEWORK}

\begin{abstract}
Riots are a phenomenon that occur spontaneously and can be challenging to predict and analyze comprehensively. In fact, individual involvement in riots is important to examine, particularly given Indonesia's history of mass violence, in order to provide a comprehensive explanation of what triggered the mass riots. Using a narrative review based on the literature published in 1990-2020, this study aims to provide a framework for understanding the psychological mechanisms of individuals involved in the May 1998 riots. This psychological framework is also expected to make a contribution to understanding the social psychology of perpetrators in similar contexts elsewhere. This study proposes three categories of attributes, which are: inter-group processes, intra-group processes, and personal characteristics. These attributes can interact with the social context so as to create individuals motivations and justifications to engage in mass violence.
\end{abstract}

Manuscript type: Original Research

\section{Article history:}

Received 22 February 2021

Received in revised form 18 May 2021

Accepted 11 June 2021

Available online 21 October 2021

\section{Keywords:}

\section{May 1998 riots}

motivation and justification

perpetrators of mass riots

psychological dynamics

\begin{abstract}
Abstrak
Kerusuhan merupakan fenomena yang terjadi secara spontan, sehingga kompleks untuk diprediksi dan dianalisis secara komprehensif. Padahal, keterlibatan individu dalam kerusuhan penting untuk diteliti, mengingat berbagai sejarah kekerasan massa yang terjadi di Indonesia, guna memberikan penjelasan yang komprehensif mengenai apa saja yang memicu kekerasan massa. Dengan menggunakan tinjauan naratif berdasarkan literatur yang diterbitkan tahun 1990-2020, studi ini bertujuan memberikan kerangka pemahaman mekanisme psikologis masyarakat yang terlibat dalam kerusuhan Mei 1998. Kerangka psikologis ini juga diharapkan dapa memberikan kontribusi untuk memahami psikologi sosial dari pelaku kerusuhan massa dalam berbagai konteks. Hasil analisis menunjukkan tiga kategori atribut utama, yaitu: proses inter-kelompok, proses intra-kelompok, dan karakteristik personal. Ketiga kategori atribut tersebut dapat berinteraksi dengan konteks sosial (seperti: faktor sosial, ekonomi, dan politik), sehingga muncul motivasi serta justifikasi untuk melakukan kekerasan massa.
\end{abstract}

Kata Kunci: dinamika psikologis, kerusuhan Mei 1998, motivasi dan justifikasi, pelaku kerusuhan massa

\section{Dampak dan Implikasi dalam Konteks Ulayat}

Dalam artikel ini, penulis berargumen bahwa memahami dinamika psikologis masyarakat yang terlibat dalam kerusuhan massa Mei 1998 akan memberikan kontribusi penting untuk memahami kompleksitas perilaku dari mereka yang terlibat dalam kerusuhan massa. Penelitian dalam bidang psikologi cenderung mengabaikan konteks sosial pada aksi kerusuhan massa karena dianggap kurang menjadi fokus penelitian dalam disiplin ilmu psikologi. Konteks sosial, seperti: faktor sosial, ekonomi, dan politik, menjadi elemen penting dalam pembentukan perilaku individu dan kelompok, serta memberikan gambaran kontekstual tentang aksi massa yang terjadi di Indonesia.

\section{Handling Editor: Made Diah Lestari, Faculty of Psychology, Universitas Udayana, Indonesia}

This open access article is licensed under Creative Commons Attribution License, which permits unrestricted use, distribution, and reproduction, provided the original work is properly cited. 


\section{PENDAHULUAN}

Aksi kerusuhan pada umumnya terjadi dengan pola identik, yakni berawal dari aksi demonstrasi atau protes yang berlangsung secara damai. Kemudian, tegangan yang terjadi antara demonstran dan aparat kerap memantik kekerasan yang melibatkan banyak massa (Ives \& Lewis, 2020; Waddington \& Moran, 2020). Mereka yang terlibat dalam kerusuhan kerap tidak hanya terdiri dari massa yang turut melakukan demonstrasi, namun juga sering kali terdiri dari massa pasif yang awalnya hanya mengobservasi dari jauh (Morrell dkk., 2011). Dapat dikatakan, mayoritas pelaku kerusuhan cenderung tidak memiliki niat untuk melakukan kekerasan tertentu sebelum aksi kerusuhan terjadi. Gambaran di atas menunjukkan bahwa kerusuhan adalah suatu aksi spontan yang kompleks untuk diprediksi dan dipahami secara mendalam.

Dengan heterogenitas etnis maupun agama di Indonesia, konflik antar agama dan antar etnis menjadi tidak terhindarkan, seperti konflik Poso, Ambon, dan Sampit. Para peneliti juga melihat adanya perbedaan sosial-ekonomi yang juga dapat ditunggangi oleh kepentingan politik (Pelly, 1999; Sarwono, 2012). Analisis psikologis terhadap orang-orang yang terlibat dalam kerusuhan sangat penting karena mereka menjadi kunci yang menjalankan aksi tersebut, meskipun bukan sebagai aktor atau dalang yang memiliki kepentingan tertentu. Dalam memahami dinamika psikologis orang-orang yang terlibat dalam kerusuhan massa, penulis membuat sebuah kerangka psikologis berdasarkan kajian literatur terhadap peristiwa kerusuhan Mei 1998 sebagai sejarah penting bagi perjalanan bangsa Indonesia hingga saat ini. Isu kerusuhan Mei 1998 sudah banyak dikaji para ilmuwan politik, sejarah, dan sosiologi (Panggabean \& Smith, 2011; Purdey, 2006; Salim, 2019; Thufail, 2007; Winarnita dkk., 2020; Winarnita \& Setiawan, 2020), namun luput menjadi perhatian bidang ilmu psikologi. Dari perspektif psikologis, penelitian terbaru dari Ahmadi (2021) berfokus pada representasi sastra dan artistik dari pengalaman traumatis perempuan-perempuan etnis Tionghoa yang mengalami pemerkosaan. Penelitian lainnya mengenai pengalaman dan reaksi korban kekerasan seksual (Sutrisno, 2002) dan stereotipe, serta diskriminasi terhadap etnis Tionghoa (Kosasih, 2010) tidak membahas dari perspektif psikologis secara mendalam. Psikologi cenderung abai dengan fenomena sosial semacam ini karena mungkin dianggap sebagai permasalahan sosial dan politik yang perlu dibereskan dalam lingkup nasional.

Dalam tulisan ini, penulis akan berfokus pada peristiwa Kerusuhan Mei 1998. Peristiwa tersebut terjadi di hampir seluruh wilayah Indonesia, memakan lebih dari seribu jiwa, dan menjadi titik balik munculnya reformasi di Indonesia (Aspinall dkk., 1999; Purdey, 2006; Tim Relawan Untuk 
Kemanusiaan, 1998). Peristiwa Mei 1998 terjadi lebih dari 20 tahun yang lalu, namun tidak ada penyelidikan secara resmi dan tuntas, baik terhadap pelaku maupun korban (Eklöf, 1999).

Meskipun tidak ada penyelidikan secara resmi terhadap kasus kerusuhan Mei 1998, berbagai penelitian berusaha menganalisis berbagai faktor terkait peristiwa tersebut dari segi peran negara dan militer sebagai aktor kerusuhan (Panggabean \& Smith, 2011; Winarnita, 2011), bagaimana media menggambarkan kerusuhan (Strassler, 2004), serta kekerasan yang berbasis gender (Heryanto, 2000; Wichelen, 2000). Namun demikian, tidak ada yang secara khusus meneliti kerusuhan Mei 1998 dari sudut pandang psikologis. Padahal, isu kerusuhan Mei 1998 erat dengan isu psikologis, di mana konflik antar etnis yang sangat terkait dengan persepsi dan pembentukan stereotipe antar individu, serta identitas individu yang melebur bersama dengan identitas kelompok. Selain itu, tidak adanya penelitian mengenai mereka yang terlibat kerusuhan Mei 1998 disebabkan oleh keterbatasan akses informasi terhadap pelaku itu sendiri karena sejauh ini tidak ada pelaku yang ditangkap atau dijatuhi hukuman, serta sensitivitas kasus Mei 1998 diprediksi akan mempersulit pengambilan data langsung terhadap orang-orang yang terlibat dalam kerusuhan. Berdasarkan penjabaran di atas, penulis merasa penting untuk melakukan kajian literatur yang bersifat naratif guna memberikan kerangka dalam memahami mekanisme psikologis orang-orang yang terlibat dalam perilaku kekerasan, secara spesifik dalam konteks kerusuhan Mei 1998. Kerangka psikologis ini diharapkan dapat memberikan kontribusi penting untuk memahami psikologi sosial dari pelaku kerusuhan massa dalam berbagai konteks.

Pendekatan psikologis dalam mengeksplorasi dinamika personal (seperti: motivasi dan justifikasi) dapat memberikan pemahaman yang baru mengenai apa yang sesungguhnya memicu kekerasan massa. Penulis melihat bahwa terdapat tiga hal yang memengaruhi perilaku kekerasan massa, yaitu: dinamika antar kelompok (seperti: stereotipe dan konflik dengan kelompok lain), dinamika intra-kelompok (seperti: norma dan identitas kelompok); dan intra-individu (seperti: kepribadian dan pengalaman hidup). Namun demikian, ketiga hal tersebut tidak dapat dipisahkan dengan konteks sosial, seperti faktor ekonomi dan politik yang melatarbelakanginya. Maka dari itu, kerangka yang penulis bangun menerangkan bahwa ketika individu terlibat dalam perilaku kekerasan massa, terdapat interaksi antara konteks sosial yang melatarbelakangi dengan dinamika antar kelompok, dinamika intra-kelompok, dan faktor intra-individu yang memotivasi untuk melakukan kekerasan massa. 


\section{METODE}

Penulis menggunakan metode kajian literatur naratif karena manusia merupakan "storied beings", sehingga memahami sesuatu dengan baik melalui cerita. Selain itu, masih cenderung belum banyak literatur mengenai peristiwa Mei 1998 serta perspektif psikologis kerusuhan yang bersifat spontan. Sebelum pencarian literatur dilakukan, penulis tidak memiliki hipotesis tertentu (lihat Gregory \& Denniss, 2018; Hodgkinson \& Ford, 2014).

Untuk penggunaan istilah, tidak ada aturan baku terkait penulisan etnis "Tionghoa" atau "Cina" dalam berbagai kajian akademik. Penulis memilih menggunakan istilah etnis "Tionghoa" dengan merujuk pada masa pemerintahan setelah Orde Baru, di mana penggunaan istilah "Tionghoa" kembali digunakan dalam berbagai pernyataan resmi, yang kemudian juga diikuti oleh media dan masyarakat umum (lihat Tan, 2008).

Dalam kajian literatur ini, penulis secara umum menggunakan Scopus dan Science Direct sebagai basis data (database) yang banyak relevan dengan penelitian dalam bidang psikologi dengan jenis artikel penelitian kualitatif dan kuantitatif, baik yang belum dan sudah dipublikasikan. Kata kunci yang dipakai ialah kerusuhan Mei 1998, kerumunan dan kekerasan massa, identitas sosial kekerasan massa, pelaku kerusuhan, dan pelaku kekerasan massa, baik dalam bahasa Indonesia maupun bahasa Inggris. Penulis tidak membatasi tahun dari sumber studi dan rata-rata menggunakan sumber data dari tahun 1990-2020. Hal ini karena penulis menganalisa peristiwa kerusuhan Mei 1998 dengan penelitian-penelitian sebelumnya mengenai identitas sosial kekerasan massa dan pelaku kekerasan massa. Dari 97 studi teridentifikasi yang relevan dengan konteks kerusuhan Mei 1998, penulis hanya memilih 73 studi yang kemudian dianalisis karena memilih studi yang lebih terbaru serta jenis kekerasan massa yang sesuai dengan konteks kerusuhan yang terjadi secara spontan. Figur 1 menjelaskan secara singkat mengenai proses seleksi studi ini.

Pada bagian selanjutnya, penulis akan menyajikan hasil eksplorasi kajian naratif yang telah dilakukan ke dalam tiga bagian. Pertama, penulis akan menjelaskan mengenai peristiwa kerusuhan Mei 1998 untuk mendapatkan gambaran mengenai kronologi peristiwa. Kedua, konteks sosial yang melatarbelakangi kerusuhan Mei 1998. Terakhir, dinamika individu dan kelompok yang membuatnya terlibat dalam kekerasan massa di kerusuhan Mei 1998, yang kemudian ditutup oleh kesimpulan dan rekomendasi. 


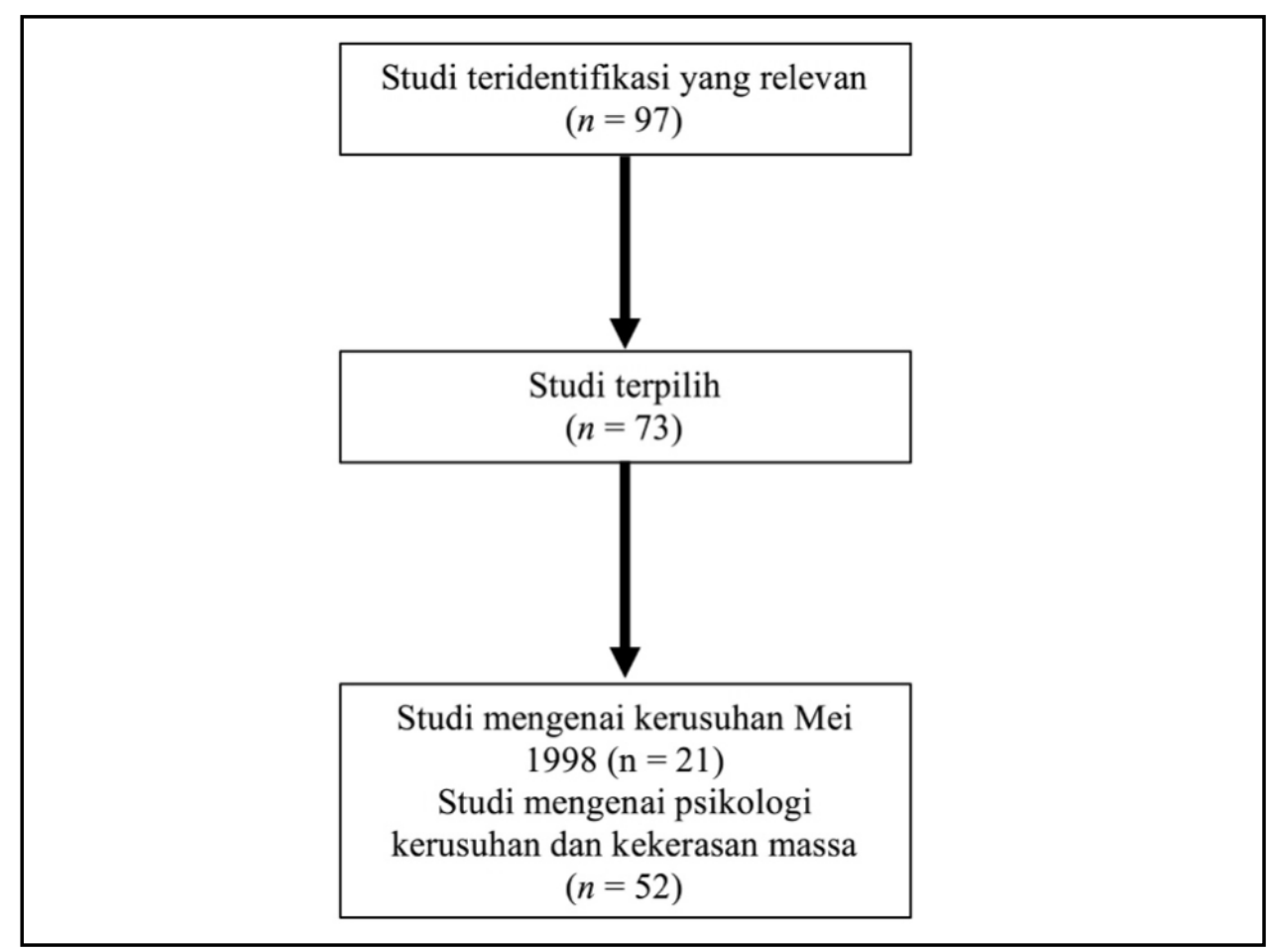

Figur 1. Proses Seleksi Studi

\section{ANALISIS DAN DISKUSI}

\section{Kronologis Kerusuhan Mei 1998}

Pada awalnya, para mahasiswa melakukan demonstrasi di beberapa daerah dengan tujuan menurunkan pemerintahan Orde Baru (1966-1998) karena kekecewaan dan ketidakpuasan terhadap pemerintah (Aspinall dkk., 1999; Purdey, 2006; Tim Relawan Untuk Kemanusiaan, 1998). Demonstrasi massa oleh para mahasiswa terjadi di berbagai wilayah, seperti Jakarta, Solo, Medan, Yogyakarta, Surabaya, dan Palembang (Panggabean \& Smith, 2011; Tim Relawan Untuk Kemanusiaan, 1998).

Demonstrasi massa yang awalnya ditujukan untuk menunjukkan kekecewaan terhadap pemerintah kemudian dimanfaatkan oleh para militer untuk mengalihkan kemarahan masyarakat, yaitu dengan mengkambinghitamkan etnis Tionghoa (etnis minoritas) sebagai penyebab krisis ekonomi yang terjadi di Indonesia (Tim Relawan Untuk Kemanusiaan, 1998). Pengkambinghitaman terhadap etnis Tionghoa dilakukan berdasarkan kondisi di mana etnis Tionghoa memegang peranan penting dalam perekonomian di Indonesia (Coppel, 1983; Purdey, 2006), dan oleh karenanya mereka dianggap memiliki peran dalam kejatuhan ekonomi di Indonesia. Selain itu, kondisi stereotipe 
masyarakat pribumi berdasarkan asosiasi kelompok etnis Tionghoa dengan komunisme dan penjajahan serta penyerangan oleh Tiongkok dimanfaatkan pemerintah untuk menciptakan iklim kekerasan terhadap masyarakat keturunan Tionghoa (Nabbs-Keller, 2020; Suryadinata, 1997).

Pada pertengahan Mei 1998, kerusuhan massa dan penjarahan terjadi di beberapa kota di Indonesia, menargetkan orang-orang beretnis Tionghoa dan harta benda milik mereka (Tan, 2006). Seperti misalnya di Medan, kerusuhan terjadi pada tanggal 6 Mei 1998, dan berakhir dengan kekerasan terhadap komunitas Tionghoa, yaitu penjarahan toko-toko milik orang Tionghoa (Purdey, 2006). Ketika kerusuhan di Medan mulai reda, terjadilah kerusuhan besar di Jakarta pada tanggal $12-$ 15 Mei 1998 (Purdey, 2006; Tim Relawan Untuk Kemanusiaan, 1998). Kerusuhan dipicu oleh penembakan yang dilakukan oleh para militer terhadap empat mahasiswa yang melakukan demonstrasi pada tanggal 12 Mei, kemudian terjadi berbagai penjarahan, perusakan toko-toko dan rumah milik orang beretnis Tionghoa, pembunuhan, dan juga kekerasan seksual, terutama terhadap para wanita dan gadis Tionghoa (Purdey, 2006; Tim Relawan Untuk Kemanusiaan, 1998).

Kerusuhan massa kemudian menyebar ke berbagai kota di Indonesia (Surabaya, Palembang, Surakarta, Boyolali) pada tanggal 14 dan 15 Mei, dan secara keseluruhan, kerusuhan massa paling besar terjadi di tiga kota, yaitu Jakarta, Solo, dan Medan (Purdey, 2006; Tim Relawan Untuk Kemanusiaan, 1998). Para peneliti memperkirakan sekitar lebih dari seribu orang yang dibunuh dan tidak diketahui secara pasti jumlah wanita Tionghoa yang diperkosa (Colombijn, 2001; Tan, 2006). Banyak orang yang melihat bingung dengan kekerasan massa yang terjadi, namun justru semakin banyak orang yang ikut terlibat dengan sebagian ingin menunjukkan kemarahan terhadap pemerintah. Seminggu kemudian, Presiden Suharto turun dari jabatannya dan berakhirlah masa pemerintahan Orde Baru (Aspinall dkk., 1999; Purdey, 2006).

\section{Konteks Sosial: Latar Belakang Peristiwa Kerusuhan Mei 1998}

Peristiwa Kerusuhan Mei 1998 dilatarbelakangi oleh faktor sosial ekonomi dan juga politik. Dalam faktor sosial ekonomi, krisis keuangan Asia tahun 1997-1998 serta kekacauan sosial dan ekonomi pada masa Orde Baru menjadi pemicu kerusuhan Mei 1998. Secara finansial, tahun 19971998, Indonesia mengalami krisis ekonomi yang berkepanjangan sebagai dampak dari krisis ekonomi Asia pada tahun 1997-1998 (Delhaise, 1998). Pada saat yang bersamaan, masyarakat semakin kecewa dengan korupsi, kolusi, dan nepotisme yang dilakukan pemerintah Orde Baru (Aspinall \& Klinken, 2010). Masyarakat menuntut reformasi dan Presiden Suharto segera turun dari jabatannya (Aspinall dkk., 1999; Tim Relawan Untuk Kemanusiaan, 1998). 
Selain kondisi ekonomi yang semakin parah, terdapat empat faktor yang memicu kerusuhan Mei 1998. Pertama, konflik antar elit politik yang ingin menurunkan pemerintahan Suharto (Aspinall dkk., 1999). Kedua, sebuah konspirasi militer untuk mengalihkan kemarahan masyarakat terhadap pemerintah dengan mengkambinghitamkan masyarakat Tionghoa (Purdey, 2006; Strassler, 2004). Ketiga, pengkambinghitaman sejak lama terhadap masyarakat Tionghoa oleh pemerintah Orde Baru (Purdey, 2006; Tan, 2006), dan yang terakhir, secara nyata, ketiadaan pasukan keamanan untuk melindungi masyarakat setempat (Heryanto, 2000; Purdey, 2006).

\section{Dinamika Individu dan Kelompok Dalam Keterlibatannya di Kerusuhan Mei 1998}

Pada bagian sebelumnya, penulis telah memberikan gambaran mengenai konteks sosial yang melatarbelakangi kerusuhan Mei 1998. Pada bagian ini, penulisberfokus pada gambaran faktor-faktor yang mendorong individu menjadi pelaku kekerasan, terutama apa yang memotivasi tindakan mereka, dan bagaimana mereka merasionalisasikan tindakannya. Pelaku kekerasan yang dimaksud ialah orang-orang yang sebelumnya menjalani kehidupan sehari-hari seperti biasa, namun dalam kondisi sosial tertentu, memilih untuk mengambil tindakan di luar batas norma. Proses dalam konteks individu yang menyebabkan terjadinya kerusuhan tersebut dapat dicermati dalam tiga tingkat analisis: 1). faktor antar kelompok, 2). faktor kelompok (intra-kelompok), dan 3). faktor individu. Konteks sosial serta ketiga faktor tersebut saling berinteraksi, sehingga pada akhirnya dapat memunculkan perilaku kekerasan massa.

\section{Perspektif Antar kelompok (Inter-kelompok)}

Area motif pertama berasal dari hubungan satu kelompok sendiri (in-group) dengan kelompok lain (out-group). Stereotipe antar kelompok dapat menciptakan perasaan benci dan hina yang dalam hubungan antar kelompok dianggap sebagai pemicu awal dari tindakan kekerasan antar kelompok (Shuman dkk., 2016; Tausch dkk., 2011). Selanjutnya, stereotipe dikaitkan dengan konflik antar kelompok dan biasa terjadi dalam konteks sosial dan politik yang menimbulkan gerakan politik massa (LaMacchia \& Louis, 2016). Secara khusus, kemarahan terhadap ketidakadilan oleh kelompok lain adalah salah satu prediktor terkuat untuk berpartisipasi dalam demonstrasi massa (Zomeren dkk., 2008). Orang-orang melakukan demonstrasi massa untuk memastikan bahwa mereka tidak lagi mengalami kerugian yang tidak adil dari kelompok luar yang menjadi ancaman bagi mereka (outgroup threat) (Drury \& Reicher, 2009). Mereka menganggap kelompok mereka sebagai korban dan tidak lagi ingin mengalami ketidakadilan tersebut (competitive victimhood) (Noor dkk. , 2008). 
Demonstrasi massa kemudian terkadang berujung pada kerusuhan yang melibatkan kekerasan massa.

Dari perspektif identitas sosial, perubahan demonstrasi menjadi kerusuhan dijelaskan dengan pemahaman bahwa identitas sosial bersama akan menentukan norma-norma yang dapat mengarahkan tindakan massa (Stott \& Drury, 2000). Saat kerusuhan muncul, maka norma yang ada dapat berupa suatu aksi kekerasan yang dianggap penting oleh kelompok. Norma ini ditetapkan oleh anggota atau pemimpin kelompok dan dianggap sebagai norma terbaik bagi anggota kelompok untuk mencapai tujuan mereka, serta mengekspresikan nilai dan perasaan mereka. Misalnya, masyarakat menganggap bahwa mereka selama ini sudah menjadi korban, sehingga perlu melakukan sesuatu demi perubahan (victim-perpetrator stereotype) (Harff \& Gurr, 2004).

Dalam konteks kerusuhan Mei 1998, banyak peneliti mengidentifikasi konflik antara masyarakat pribumi dan Tionghoa, antara masyarakat dengan pemerintah, antara wanita dan pria sebagai faktor yang memicu kekerasan di peristiwa Mei 1998 Herlijanto, 2000; Heryanto, 2000). Konflik tersebut merupakan konflik antar kelompok yang sering menjadi fokus analisis suatu kekerasan massa. Banyak perspektif antar kelompok yang penting untuk dicermati, namun sayangnya observasi terhadap dinamika kelompok dan faktor individu cenderung diabaikan. Jarang terdapat penelitian yang melihat hubungan antar ketiganya (inter-kelompok, intra-kelompok, dan individu), biasanya hanya salah satu dari ketiga dimensi konflik tersebut. Dengan demikian, diperlukan analisa yang lebih komprehensif dalam menjelaskan perilaku kekerasan massa.

\section{Perspektif Kelompok (Intra-kelompok)}

Motif kedua dalam melakukan kekerasan massa berasal dari proses intra-kelompok. Individu dalam suatu kelompok tidak hanya memiliki identitas pribadi (rasa "saya"), tetapi juga identitas sosial (rasa "kami”) yang dimiliki bersama dengan anggota kelompok lainnya (Tajfel \& Turner, 1979). Tajfel (1978, hlm. 63) mendefinisikan identitas sosial sebagai "bagian dari konsep diri individu yang berasal dari pengetahuannya tentang keanggotaannya dalam suatu kelompok sosial (atau kelompok) bersama dengan signifikansi nilai dan emosi yang melekat pada keanggotaan itu”. Menurut teori identitas sosial, kita masing-masing memiliki banyak identitas sosial yang dapat menjadi aktif dalam berbagai lingkungan sosial (Turner dkk., 1994). Ketika identitas seseorang sebagai anggota dari satu kelompok menjadi kokoh, identitas dalam kelompok itu (misalnya, sebagai perempuan) membuatnya lebih menonjol dibandingkan dengan identitas lainnya yang berbeda (misalnya, sebagai laki-laki). Dengan demikian, identitas sosial yang kokoh menciptakan dan mencerminkan perbedaan "kitamereka" yang kuat. 
Reicher (1982) kemudian mengembangkan teori identitas sosial untuk menjelaskan perilaku kerumunan ( crowd). Berbeda dengan teori umum tentang perilaku kerumunan sebagai tindakan bodoh dan irasional (LeBon, 1895), dalam teori identitas sosial, ketika orang bertindak dalam peristiwa kerumunan, tindakan mereka tidak dimanipulasi oleh orang lain dalam suatu kelompok, tetapi disebabkan oleh identitas sosial yang sama dengan norma bersama (standar atau aturan perilaku) yang mengarahkan suatu tindakan. Perilaku kerumunan bukan hasil dari individualitas yang kabur dan disorientasi, tetapi sebagai hasil dari individu yang mendefinisikan dirinya sebagai bagian dari kelompok besar. Perilaku kerumunan dimotivasi oleh identitas sosial yang relevan dengan kelompok, sehingga individu dapat bertindak secara spontan tanpa adanya kepemimpinan dan pengambilan keputusan yang formal (Stott \& Drury, 2017).

Dalam konteks kerusuhan massa Mei 1998, orang-orang yang bergabung dalam kegiatan massa (misalnya, demonstrasi yang kemudian memancing kerusuhan) memiliki tujuan tertentu dan ekspektasi mengenai apa yang akan terjadi berikutnya. Saat aksi demonstrasi berubah menjadi kerusuhan, seringkali terjadi perubahan pemahaman massa tentang norma dan identitas sosial kolektifnya. Hal ini dapat terjadi melalui dua jalur, yaitu pidato yang menghasut kekerasan sebagai entrepreneurship of identity (misalnya, dengan memposisikan kerumunan sebagai bagian dari kelompok yang dirugikan, dengan kewajiban untuk membalas kelompok yang merugikan demi pertahanan kelompok di masa depan), dan provokasi terhadap situasi keamanan, di mana kemudian kerumunan diserang oleh polisi dan massa menjadi yakin akan kebobrokan dari pihak-pihak yang berwenang (Haslam dkk., 2011; Reicher \& Hopkins, 2003).

Saat berbagai norma sudah terbentuk dalam kekerasan massa, norma tersebut menyebar melalui proses antar individu di dalam kelompok (intra-kelompok) (Turner dkk., 1987). Dalam kasus kerusuhan, sensasi dan pengalaman baru yang signifikan mendorong rasa kesatuan dalam kelompok yang besar dan identifikasi sosial yang kuat. Identitas sosial yang kuat kemudian meningkatkan konformitas individu dengan norma sosial, baik untuk tindakan kekerasan atau non-kekerasan (Louis dkk., 2004). Dalam konteks kekerasan massa, misalnya saat individu di tengah kerusuhan Mei 1998 mengamati bahwa orang lain dalam kelompok yang sama melakukan kekerasan (misalnya, mereka berasal dari kelompok etnis yang sama), individu lebih cenderung melakukan tindakan yang sama demi solidaritas kelompok (Fujii, 2009; McDoom, 2013).

Selain itu, dalam konteks kekerasan seksual, pelaku didominasi oleh laki-laki. Kekerasan seksual massa terkait dengan maskulinitas dan dominansi laki-laki (Franklin, 2004). Pelaku ingin menunjukkan maskulinitas, dominansi sosial, dan kekuasaan mereka terhadap wanita sebagai 
kelompok yang mereka anggap lemah. Melakukan kekerasan seksual dianggap sebagai cara untuk mempererat ikatan antar sesama laki-laki. Kekerasan seksual massa atau pemerkosaan massal ialah lebih kepada rasa memiliki antar sesama laki-laki yang sama-sama memiliki kebutuhan akan kekuasaan, dominansi, dan ikatan dalam suatu kelompok sosial daripada kebutuhan seksual secara pribadi semata (Groth \& Birnbaum, 1979; O’Sullivan, 1991).

Ketika para peneliti mengidentifikasi peran persuasi dari media dan pihak-pihak yang berwenang (para elite/atasan), hal ini dapat terkait dengan apa yang disebut dengan norma kelompok dan "bisnis identitas" (Haslam dkk., 2011; Reicher \& Hopkins, 2003). Namun, tidak ada cukup data yang melihat perdebatan atau konflik dari norma-norma tersebut dan bagaimana area yang tidak terdapat aksi kerusuhan menentang perubahan norma tersebut. Hal ini dapat menjadi arahan untuk penelitian pada masa mendatang.

\section{Faktor Individu (Karakteristik Personal)}

Area motif yang ketiga ialah faktor individu, di mana belum pernah ada yang menganalisa secara khusus area ini terkait kerusuhan Mei 1998. Penelitian sebelumnya menunjukkan bahwa ciriciri pribadi yang umumnya dimiliki oleh individu yang rentan melakukan kekerasan massa antara lain: 1) impulsivitas tinggi (Derefinko dkk., 2011; Friese \& Hofmann, 2009; L'Abate, 1993); 2) tingkat agresivitas yang tinggi (Dodge dkk., 1994; Morales \& Guerra, 2006; Pouwels \& Cillessen, 2013); 3) mencari sensasi (thrill-seeking) (Baumeister \& Campbell, 1999; Newburn dkk., 2015; Presdee, 2000); dan 4) kebutuhan tinggi terhadap kebutuhan pokok (Bauman, 2007; Lewis dkk., 2011; Newburn dkk., 2015). Di bawah ini, akan dijelaskan lebih lanjut mengenai keempat karakteristik tersebut, di mana setiap individu yang melakukan kerusuhan Mei 1998 dapat memiliki salah satu, beberapa, atau bahkan seluruh karakteristik tersebut.

\section{Impulsivitas Tinggi}

Sejak lama, perilaku kekerasan dikaitkan dengan impulsivitas dalam diri seseorang (Derefinko dkk., 2011; Miller dkk., 2012). Hal ini terkait dengan bagaimana seseorang mengontrol dirinya, terutama dalam meluapkan emosi negatif, di mana seseorang kurang memikirkan dampak panjang dari tindakannya. Perilaku impulsif dapat diperoleh melalui pembelajaran dalam keluarga, yaitu berdasarkan pola asuh dari orang tua (L'Abate, 1993). Impulsivitas ditunjukkan dengan bereaksi segera tanpa memikirkan konsekuensi dari perilakunya, dan tidak memiliki kontrol yang kuat, sehingga tidak mampu menunda kepuasan atau emosi negatif dalam diri. 
Impulsivitas yang tinggi berkaitan dengan perilaku agresif. Dodge dkk. (1994) mengungkapkan bahwa terdapat hipotesis mengenai hubungan antara proses berespons dalam situasi sosial dengan perilaku agresif yang dimoderasi oleh impulsivitas. Secara spesifik, penilaian positif terhadap respons agresif lebih menentukan perilaku agresif di kemudian hari pada individu yang memiliki impulsivitas tinggi dibandingkan individu dengan impulsivitas rendah. Hal tersebut disebabkan karena individu dengan impulsivitas tinggi lebih kecil kemungkinannya untuk mengolah informasi secara seksama dan mempertimbangkan konsekuensi dari tindakannya pada masa mendatang.

\section{Tingkat Agresivitas Yang Tinggi}

Beberapa studi mengemukakan bahwa paparan terhadap kekerasan dapat memprediksi perilaku agresif pada masa mendatang, dan hal tersebut lebih banyak terjadi pada laki-laki (Morales \& Guerra, 2006; Pouwels \& Cillessen, 2013). Dikatakan juga bahwa jumlah stresor yang dimiliki individu memprediksi perilaku agresif pada masa kini dan mendatang (Seifer \& Sameroff, 1987).

\section{Mencari Sensasi (Thrill-seeking)}

Perilaku orang-orang yang terlibat dalam kerusuhan berkisar dari yang tidak terlibat sama sekali, hanya melihat dari jauh, melakukan protes, turut melakukan kekerasan, dan juga menjarah (Morrell dkk., 2011). Reicher, Levine, Gordijn (1998) mengemukakan bahwa perusuh yang berada di jalan atau lokasi kerusuhan memiliki berbagai macam motivasi, yaitu hanya ingin melihat apa yang sedang terjadi, ikut merasakan kegembiraan, untuk melakukan protes, atau untuk melawan polisi. Banyak yang awalnya terlibat dalam kerusuhan karena dipicu oleh kegairahan dalam situasi rusaknya tatanan sosial dan hukum. Bagi beberapa perusuh, keterlibatan mereka berasal dari konstruksi “identitas kegembiraan dan pertentangan", di mana mereka merasa kerusuhan lebih kepada tindakan “pesta" daripada "kriminal”, atau justru mengalami campuran keduanya (Presdee, 2000).

Beberapa orang menganggap kerusuhan sebagai kesempatan untuk merasakan sensasi yang tidak pernah mereka rasakan dalam situasi sehari-hari. Mereka yang merasa jenuh dalam menjalankan rutinitas (serta berjumpa dengan permasalahan sehari-hari) akan lebih mudah terlibat dalam situasi kerusuhan, terutama dalam kasus penjarahan, di mana terdapat campuran perasaan senang, panik, heboh, dan kegilaan sementara (Young, 2011). Kekacauan yang umumnya tidak direncanakan, yang dipicu oleh kegembiraan dan sensasi pelanggaran adalah hal signifikan yang muncul dari kesaksian para perusuh (Newburn dkk., 2015). 
Beberapa penelitian menunjukkan bahwa, dengan berkelahi dengan polisi saat kerusuhan, perusuh memiliki keinginan yang kuat untuk merasakan sensasi kegembiraan dan perasaan senang (Elias \& Dunning, 1970; Spaaij, 2008). Adrenalin yang muncul ketika berkelahi dengan orang lain bisa menghilangkan kebosanan dan mengalami gairah emosional yang besar (Kerr, 2005; Spaaij, 2008). Lebih lanjut, dalam kasus kerusuhan London pada tahun 2011, satu studi besar menemukan bahwa banyak orang bergabung dalam kerumunan beberapa jam setelah kerusuhan dimulai (Stott dkk., 2011). Saat malam semakin larut, semakin banyak orang bergabung dalam kerusuhan yang semakin melelahkan para polisi. Dengan merusak properti, massa memiliki kesempatan untuk berhadapan dengan polisi dan melecehkan mereka, dan hal tersebut tidak mungkin terjadi dalam situasi sehari-hari, di mana polisi lebih dominan. Para massa senang dengan kemampuan mereka mengubah situasi biasa walaupun mereka menyadari kondisi tersebut hanya sementara (Stott dkk., 2011). Dengan ini, dapat dikatakan bahwa kegembiraan yang pada awalnya dirasakan tanpa alasan atau konteks yang spesifik dapat berubah menjadi kegembiraan dari kesempatan yang menegangkan untuk melawan otoritas dan merayakan pelanggaran yang dilakukan.

\section{Kebutuhan Tinggi Terhadap Kebutuhan Pokok}

Para perusuh menganggap kerusuhan jarang terjadi, di mana kejadian tersebut dianggap sebagai "moral holiday" (ketiadaan moral) (Collins, 2008). Ketiadaan moral untuk sementara waktu memungkinkan orang untuk terlibat dalam penjarahan dan sebagian orang dimotivasi oleh kebutuhan material (konsumerisme). Sebagian orang yang terlibat dalam kerusuhan bertujuan mendapatkan barang kebutuhan pokok, yang dalam kehidupan sehari-hari mereka bekerja keras untuk mendapatkannya (Newburn dkk., 2015). Beberapa orang ingin mendapatkan barang-barang mewah (Lewis dkk., 2011). Orang-orang seperti itu mengambil kesempatan untuk merasakan bagaimana memiliki barang dengan usaha yang minim dan memilih untuk terlibat dalam penjarahan karena berpikir bahwa mereka tidak akan pernah memiliki kesempatan yang sama jika tidak terlibat.

Belum pernah ada penelitian mengenai individu pelaku dalam kerusuhan Mei 1998, sehingga tidak ada pertimbangan analisis mengenai motif-motif yang dimiliki individu pelaku. Penelitian di masa mendatang diperlukan untuk mengeksplorasi sejauh mana motif-motif seperti impulsivitas yang tinggi, tingkat agresivitas yang tinggi, mencari sensasi, dan kebutuhan tinggi terhadap kebutuhan pokok berperan dalam keterlibatan individu dalam kerusuhan Mei 1998.

Tabel 1 di bawah ini merangkum pembahasan sebelumnya, di mana merupakan temuantemuan utama dari penelitian sebelumnya tentang berbagai karakteristik dan rasionalisasi individu 
dalam aspek inter-kelompok, intra-kelompok, dan pribadi, yang dapat dipicu saat peristiwa kekerasan massa. Dalam beberapa kasus, sebuah variabel dapat muncul di kedua kolom karena beberapa justifikasi juga merupakan faktor yang memotivasi tindakan kekerasan. Tidak semua karakteristik dan atribut yang ditulis dalam tabel dibutuhkan seseorang untuk melakukan kekerasan massa. Atribut tertentu akan berhubungan dengan bentuk kejahatan tertentu (misalnya: pencari sensasi mungkin akan lebih cenderung untuk menjarah, sementara orang dengan agresivitas tinggi mungkin akan lebih cenderung melakukan kekerasan fisik).

Tabel 1.

Analisa Masyarakat Biasa Menjadi Pelaku Kekerasan Massa

\begin{tabular}{|c|c|c|}
\hline Level Analisa & Atribut Mengarah ke Motif & $\begin{array}{c}\text { Justifikasi } \\
\end{array}$ \\
\hline \multirow{3}{*}{$\begin{array}{l}\text { Inter-kelompok } \\
\text { (antar kelompok) }\end{array}$} & $\begin{array}{l}\text { Stereotipe kelompok antar masyarakat: } \\
\text { Pribumi \& Tionghoa, laki-laki \& perempuan } \\
\text { (Drury \& Reicher, 2009; Sanday, 2007) }\end{array}$ & $\begin{array}{l}\text { Kelompok luar sebagai } \\
\text { ancaman (outgroup threat) } \\
\text { (Drury \& Reicher, 2009) }\end{array}$ \\
\hline & $\begin{array}{l}\text { Stereotipe masyarakat terhadap pemerintah (Drury } \\
\text { \& Reicher, 2009; Shuman dkk., 2016) }\end{array}$ & $\begin{array}{l}\text { Kelompok kami sebagai } \\
\text { korban (competitive } \\
\text { victimhood) (Noor dkk., 2008) }\end{array}$ \\
\hline & & $\begin{array}{l}\text { Stereotip korban-pelaku } \\
\text { (victim-perpetrator } \\
\text { stereotypes) (Harff \& Gurr, } \\
\text { 2004) }\end{array}$ \\
\hline \multirow[b]{2}{*}{$\begin{array}{l}\text { Intra-kelompok } \\
\text { (dalam kelompok) }\end{array}$} & $\begin{array}{l}\text { Konformitas terhadap kelompok karena ada rasa } \\
\text { memiliki (belongingness) (Louis dkk., 2004; } \\
\text { Reicher, 1984) }\end{array}$ & $\begin{array}{l}\text { Rasa solidaritas (Fujii, 2009; } \\
\text { McDoom, 2013; Spaaij, 2008) }\end{array}$ \\
\hline & $\begin{array}{l}\text { Konformitas terhadap kelompok karena ada ikatan } \\
\text { \& rasa dominan sebagai laki-laki (Franklin, 2004; } \\
\text { Kimmel, 1994) }\end{array}$ & $\begin{array}{l}\text { Mempertahankan atau } \\
\text { mendapatkan status \& } \\
\text { kekuasaan (Boswell \& Spade, } \\
\text { 1996; Griffin, 1986; Kaufman, } \\
\text { 1997) }\end{array}$ \\
\hline \multirow{5}{*}{ Personal } & $\begin{array}{l}\text { Impulsivitas tinggi (Derefinko dkk., 2011; Friese } \\
\text { \& Hofmann, 2009; L’Abate, 1993) }\end{array}$ & $\begin{array}{l}\text { Perilaku yang dipelajari dalam } \\
\text { keluarga (Friese \& Hofmann, } \\
\text { 2009; L'Abate, 1993) }\end{array}$ \\
\hline & $\begin{array}{l}\text { Tingkat agresivitas yang tinggi (Dodge dkk., 1994; } \\
\text { Morales \& Guerra, 2006; Pouwels \& Cillessen, } \\
\text { 2013) }\end{array}$ & $\begin{array}{l}\text { Paparan tinggi terhadap } \\
\text { kekerasan (Dodge dkk., 1994; } \\
\text { Morales \& Guerra, 2006) }\end{array}$ \\
\hline & $\begin{array}{l}\text { Mencari sensasi (thrill-seeking) (Baumeister \& } \\
\text { Campbell, 1999; Newburn dkk., 2015; Presdee, } \\
\text { 2000) }\end{array}$ & $\begin{array}{l}\text { Perasaan senang mendapat } \\
\text { sensasi (Baumeister \& } \\
\text { Campbell, 1999; Taubman- }\end{array}$ \\
\hline & Kebutuhan tinggi terhadap kebutuhan & Ben-Ari, 2004) \\
\hline & $\begin{array}{l}\text { pokok(Bauman, 2007; Lewis dkk., 2011; Newburn } \\
\text { dkk., 2015) }\end{array}$ & $\begin{array}{l}\text { Kesempatan langka (Collins, } \\
\text { 2008; Newburn dkk., 2015) }\end{array}$ \\
\hline
\end{tabular}




\section{SIMPULAN DAN SARAN}

\section{Simpulan}

Ketiga kategori atribut yang dijelaskan di atas (proses inter-kelompok, proses intra-kelompok, dan karakteristik personal) tidak berinteraksi sendiri tanpa adanya konteks sosial yang melatarbelakanginya. Jadi, dalam menganalisis motivasi yang mendasari masyarakat untuk terlibat dalam kekerasan massa, perlu melihat konteks sosial dan interaksinya dengan individu dan kelompok. Dalam konteks kerusuhan Mei 1998 secara spesifik, baik mekanisme psikologis di dalam dan di antara individu dan kelompok, serta konteks sosial ekonomi dan politik yang melatarbelakangi menjadi penting dalam memahami bagaimana masyarakat menjelaskan motivasi mereka terlibat dalam kerusuhan, dan bagaimana mereka membenarkan tindakan mereka.

\section{Saran}

Studi ini memperkaya literatur mengenai psikologi sosial masyarakat yang terlibat dalam kekerasan massa secara umum dalam konteks Indonesia. Pada masa mendatang, diharapkan ada kesempatan untuk meneliti langsung masyarakat yang terlibat dalam kerusuhan, baik kerusuhan Mei 1998 atau kejadian serupa di Indonesia.

Penemuan-penemuan mengenai keterlibatan masyarakat dalam kekerasan massa dapat menjadi referensi untuk memberikan sumbangsih dalam mencegah kejadian-kejadian serupa di masa mendatang. Dalam mencegah kejadian serupa, misalnya dapat dilakukan pembekalan karakter positif pada tingkat individu dan penanaman identitas dan norma-norma positif pada taraf kelompok karena masyarakat biasa yang terlibat menjadi kunci dalam suatu kekerasan massa.

\section{SPONSOR}

Penelitian ini sebagai bagian dari studi doktoral penulis pertama, yang mendapatkan dukungan beasiswa dari The University of Queensland, Australia, melalui mekanisme Research Training Program (RTP) Awards.

\section{ASPEK ETIK STUDI}

\section{Pernyataan Etik}

Studi ini tidak memerlukan evaluasi etik karena berupa kajian literatur. 


\section{Konflik Kepentingan}

Para penulis melaporkan bahwa tidak ada konflik kepentingan dalam studi ini.

\section{Ketersediaan Data}

Seluruh data dalam kajian literatur ini dapat diakses langsung oleh publik dengan mengacu pada seluruh referensi yang ditampilkan.

\section{REFERENSI}

Ahmadi, A. (2021). The traces of oppression and trauma to ethnic minorities in Indonesia who experienced rape on the 12 May 1998 tragedy: A review of literature. Journal of Ethnic and Cultural Studies, 8(2), 126-144. https://doi.org/10.29333/ejecs/744

Aspinall, E., Feith, H., \& Klinken, G. (1999). The last days of president suharto. Monash Asia Institute.

Aspinall, E., \& Klinken, G.. (2010). The state and illegality in Indonesia. KITLV Press.

Bauman, Z. (2007). Collateral casualties of consumerism. Journal of Consumer Culture, 7(1), 25-56. https://doi.org/10.1177/1469540507073507

Baumeister, R. F., \& Campbell, W. K. (1999). The intrinsic appeal of evil: Sadism, sensational thrills, and threatened egotism. Personality and Social Psychology Review, 3(3), 210-221. https://doi.org/10.1207/s15327957pspr0303_4

Boswell, A., \& Spade, J. Z. (1996). Fraternities and collegiate rape culture: Why are some fraternities more dangerous places for women? Gender \& Society, 10(2), 133-147. https://doi.org/10.1177/089124396010002003

Collins, R. (2008). Violence: A micro-sociological theory. Princeton University Press.

Colombijn, F. (2001). What is so Indonesian about violence? Dalam I. Wessel \& D. Wimhofer (Eds.), Violence in Indonesia (hlm. 25-46). Abera Verlag Markus Voss.

Coppel, C. A. (1983). Indonesian Chinese in crisis. Oxford University Press.

Delhaise, P. (1998). Asia in crisis: The implosion of the banking and finance systems. John Wiley \& Sons.

Derefinko, K., DeWall, C. N., Metze, A. V., Walsh, E., \& Lynam, D. R. (2011). Do different facets of impulsivity predict different types of aggression? Aggressive Behavior, 37(3), 223-233. https://doi.org/10.1002/ab.20387 
Dodge, K. A., Pettit, G. S., \& Bates, J. E. (1994). Socialization mediators of the relation between socioeconomic status and child conduct problems. Child Development, 65, 649-665. https://doi.org/10.1111/j.1467-8624.1994.tb00774.x

Drury, J., \& Reicher, S. D. (2009). Collective psychological empowerment as a model of social change: Researching crowds and power. Journal of Social Issues, 65(4), 707-725. https://doi.org/10.1111/j.1540-4560.2009.01622.x

Eklöf, S. (1999). Indonesian Politics in crisis: The long fall of suharto, 1996-1998 (Vol. 1). NIAS Press.

Elias, N., \& Dunning, E. (1970). The quest for excitement in unexciting societies. Dalam G. Luschen (Ed.), The cross-cultural analysis of sport and games (hlm. 31-51). Stipes.

Franklin, K. (2004). Enacting masculinity: Antigay violence and group rape as participatory theater. Sexuality Research \& Social Policy, 1(2), 25-40. https://doi.org/10.1525/srsp.2004.1.2.25

Friese, M., \& Hofmann, W. (2009). Control me or I will control you: Impulses, trait self-control, and the guidance of behavior. Journal of Research in Personality, 43(5), 795-805. https://doi.org/10.1016/j.jrp.2009.07.004

Fujii, L. A. (2009). Killing neighbours: Webs of violence in Rwanda. Cornell University Press.

Gregory, A. T., \& Denniss, A. R. (2018). An introduction to writing narrative and systematic reviews_-Tasks, tips and traps for aspiring authors. Heart, Lung and Circulation, 27(7), 893898. https://doi.org/10.1016/j.hlc.2018.03.027

Griffin, S. (1986). Rape: The politics of consciousness. HarperCollins.

Groth, A. N., \& Birnbaum, H. J. (1979). Men who rape: The psychology of the offender. Plenum.

Harff, B., \& Gurr, R. T. (2004). Ethnic conflict in world politics. Westview.

Haslam, S. A., Reicher, S. D., \& Platow, M. J. (2011). The new psychology of leadership: identity, influence, and power. Psychology Press.

Herlijanto, J. (2004). The May 1998 riots and the emergence of Chinese Indonesians: Social movements in the post-soeharto era. [Paper presentation]. 18th Conference of International Association of Historians of Asia (IAHA), Taipei.

Heryanto, A. (2000). Perkosaan Mei 1998: Beberapa pertanyaan konseptual (The May 1998 rapes: Several conceptual questions). Dalam N. I. Subono (Ed.), Negara dan kekerasan terhadap perempuan (The state and violence towards women) (hlm. 57-97). Yayasan Jurnal Perempuan and Asia Foundation. 
Hodgkinson, G. P., \& Ford, J. K. (2014). Narrative, meta-analytic, and systematic reviews: What are the differences and why do they matter? Journal of Organizational Behavior, 35(S1), S1-S5.

Ives, B., \& Lewis, J. S. (2020). From rallies to riots: Why some protests become violent. Journal of Conflict Resolution, 64(5), 958-986. https://doi.org/10.1177/0022002719887491

Kaufman, M. (1997). The construction of masculinity and the triad of men's violence. Dalam L. O. T. J. R. Schiffman (Ed.), Gender Violence: Interdisciplinary Perspectives. New York University Press.

Kerr, J. H. (2005). Rethinking aggression and violence in sport. Routledge.

Kimmel, M. S. (1994). Masculinity as homophobia: Fear, shame, and silence in the construction of gender identity. Dalam H. B. M. Kaufman (Ed.), Theorizing masculinities (hlm. 119-141). Sage.

Kosasih, L. S. (2010). Chinese Indonesians: Stereotyping, discrimination and anti-Chinese violence in the context of structural changes up to May 1998 riots. [Master Thesis]. Utrecht University, Netherlands. https://dspace.library.uu.nl/handle/1874/179217

L'Abate, L. (1993). A family theory of impulsivity. Dalam W. G. McCown, J. L. Johnson, \& M. B. Shure (Eds.), Theory, Research, and Treatment (hlm. 93-117). American Psychological Association.

LaMacchia, S. T., \& Louis, W. R. (2016). Crowd behaviour and collective action. Dalam S. McKeown, R. Haji, \& N. Ferguson (Eds.), Understanding peace and conflict through social identity theory. Springer International.

LeBon, G. (1895). The crowd: A study of the popular mind. T. Fisher Unwin.

Lewis, P., Newburn, T., Ball, J., Robert, P., Vis, F., \& Voss, A. (2011). Reading the riots: Investigating England's summer of disorder. London School of Economics and Political Science and The Guardian.

Louis, W. R., Taylor, D. M., \& Neil, T. (2004). Cost-benefit analyses for your group and yourself: The rationality of decision-making in conflict. International Journal of Conflict Management, 15, 110-143. https://doi.org/10.1108/eb022909

McDoom, O. S. (2013). Antisocial capital: A profile of Rwandan genocide perpetrators' social networks. Journal of Conflict Resolution, 58(5), 865-893. https://doi.org/10.1177/0022002713484282 
Miller, J. D., Zeichner, A., \& Wilson, L. F. (2012). Personality correlates of aggression: evidence from measures of the five-factor model, UPPS model of impulsivity, and BIS/BAS. Journal of Interpersonal Violence, 27(14), 2903-2919. https://doi.org/10.1177/0886260512438279

Morales, J., \& Guerra, N. G. (2006). Effects of multiple context and cumulative stress on urban children's adjustment in elementary school. Child Development, 77(4), 907-923. https://doi.org/10.1111/j.1467-8624.2006.00910.x

Morrell, G., Scott, S., McNeish, D., \& Webster, S. (2011). The August riots in England: Understanding the involvement of young people. NatCen.

Nabbs-Keller, G. (2020). The contending domestic and international imperatives of Indonesia's China challenge. Australian Journal of Defence and Strategic Studies, 2(2), 189-214.

Newburn, T., Cooper, K., Deacon, R., \& Diski, R. (2015). Shopping for free? Looting, consumerism, and the 2011 riots. The British Journal of Criminology, 55(5), 987-1004. https://doi.org/10.1093/bjc/azv007

Noor, M., Brown, R., \& Prentice, G. (2008). Prospects for intergroup reconciliation: Socialpsychological predictors of intergroup forgiveness and reparation in Northern Ireland and Chile. Dalam T. E. M. A. Nadler, \& J.D. Fisher (Eds.), The social psychology of intergroup reconciliation (hlm. 97-114). Oxford University Press.

O’Sullivan, C. S. (1991). Acquaintance gang rape on campus. Dalam A. Parrot \& L. Bechhofer (Eds.), Acquaintance rape: The hidden crime (hlm. 140-156). John Wiley \& Sons.

Panggabean, S. R., \& Smith, B. (2011). Explaining anti-Chinese riots in late 20th century Indonesia. World Development, 39(2), 231-242. https://doi.org/10.1016/j.worlddev.2009.11.036

Pelly, U. (1999). Akar kerusuhan etnis di Indonesia: Suatu kajian awal konflik dan disintegrasi nasional di era reformasi. Antropologi Indonesia, (58), 27-35. https://doi.org/10.7454/ai.v0i58.3363

Pouwels, J. L., \& Cillessen, A. H. (2013). Correlates and outcomes associated with aggression and victimization among elementary-school children in a low-income urban context. Journal of Youth and Adolescence, 42(2), 190-205. https://doi.org/10.1007/s10964-012-9875-3

Presdee, M. (2000). Cultural criminology and the carnival of crime. Routledge.

Purdey, J. (2006). Anti-Chinese violence in Indonesia, 1996-1999. University of Hawaii Press.

Reicher, S. D. (1982). The determination of collective bahaviour. Dalam H. Tajfel (Ed.), Social identity and intergroup relations (hlm. 41-84). Cambridge University Press. 
Reicher, S. D. (1984). Social influence in the crowd: Attitudinal and behavioral effects of deindividuation in conditions of high and low group salience. British Journal of Social Psychology, 23(4), 341-350. https://doi.org/10.1111/j.2044-8309.1984.tb00650.x

Reicher, S. D., \& Hopkins, N. (2003). On the science of the art of leadership. Dalam D. van Knippenberg \& M. Hogg (Eds.), Leadership and power: Identity process in groups and organizations (hlm. 45-62). Sage.

Salim, L. (2019). Dinamika konflik kerusuhan Mei 1998 di Kota Surakarta melalui perspektif korban. Journal of Development and Social Change, 3(1), 58-71.

Sanday, P. G. (2007). Fraternity gang rape: Sex, brotherhood, and privilege on campus (2nd ed.). New York University Campus.

Sarwono, S. W. (2012). Terorisme di Indonesia: Dalam tinjauan psikologi. Pustaka Alvabet.

Seifer, R., \& Sameroff, A. J. (1987). Multiple determinants of risk and vulnerability. Dalam E. J. Anthony \& B. J. Cohler (Eds.), The invulnerable child (hlm. 51-69). Guilford.

Shuman, E., Cohen-Chen, S., Hirsch-Hoefler, S., \& Halperin, E. (2016). Explaining normative versus nonnormative action: The role of implicit theories. Political Psychology, 37(6), 835-852. https://doi.org/10.1111/pops. 12325

Spaaij, R. (2008). Men like us, boys like them: Violence, masculinity, and collective identity in football hooliganism. Journal of Sport \& Social Issues, 32(4), 369-392. https://doi.org/10.1177/0193723508324082

Stott, C., \& Drury, J. (2000). Crowds, context and identity: Dynamic categorization processes in the 'poll tax riot'. Human Relations, 53(2), 247-273. https://doi.org/10.1177/a010563

Stott, C., Drury, J., \& Reicher, S. D. (2011). On the role of a social identity analysis in articulating structure and collective action: The 2011 riots in Tottenham and Hackney. The British Journal of Criminology, 57(4), 964-981. https://doi.org/10.1093/bjc/azw036

Strassler, K. (2004). Gendered visibilities and the dream of transparency: The Chinese Indonesian rape debate in post-suharto Indonesia. Gender \& History, 16(3), 689-725. https://doi.org/10.111/j.0953-5233.2004.00361.x

Suryadinata, L. (1997). Ethnic Chinese in Southeast Asia: Overseas Chinese, Chinese overseas or Southeast Asian. Dalam L. Suryadinata (Ed.), Ethnic Chinese as Southeast Asian (hlm. 1-24). Institute of Southeast Asian Studies.

Sutrisno, E. L. (2002). The May 1998 riot in Surabaya: Through the local people's narratives. [Master Thesis]. University of Amsterdam, Netherlands. 
https://www.academia.edu/43828805/The_May_1998_Riot_in_Surabaya_Through_the_Loc al_Peoples_Narratives

Tajfel, H. (1978). Differentiation between social groups: Studies in the social psychology of intergroup relations. Academic Press.

Tajfel, H., \& Turner, J. C. (1979). An integrative theory of intergroup conflict. Dalam W. G. Austin \& S. Worchel (Eds.), The social psychology of intergroup relations (hlm. 33-47). Brooks/Cole.

Tan, M. G. (2008). Etnis Tionghoa di Indonesia: Kumpulan tulisan. Yayasan Obor Indonesia.

Taubman-Ben-Ari, O. (2004). Risk taking in adolescence. Dalam S. L. K. J. Greenberg, \& T. Pyszczynski (Eds.), Handbook of experimental existential psychology (hlm. 106-124). Guilford Press.

Tausch, N., Becker, J., Spears, R., Christ, O., Saab, R., Singh, P., \& Siddiqui, R. (2011). Explaining radical group behavior: Developing emotion and efficacy routes to normative and nonnormative collective action. Journal of Personality and Social Psychology, 101(1), 129148. https://doi.org/10.1037/a0022728

Thufail, F. I. (2007). Figures in the May 1998 riots: Imagining the state in post-new order Indonesia. [Doctoral Dissertation]. University of Wisconsin-Madison, Wisconsin. http://hdl.handle.net/11858/00-001M-0000-0011-97A5-2

Tim Relawan Untuk Kemanusiaan. (1998). Temuan tim gabungan pencari fakta peristiwa kerusuhan Mei 1998. Komnas Perempuan. https://komnasperempuan.go.id/instrumen-ham-perempuandetail/seri-dokumen-kunci-2-temuan-tim-gabungan-pencari-fakta-peristiwa-kerusuhan-mei1998-lampiran-laporan-tim-relawan-untuk-kemanusiaan

Turner, J. C., Hogg, M. A., Oakes, P. J., Reicher, S. D., \& Wetherell, M. S. (1987). Rediscovering the social group: A self-categorization theory. Blackwell Publishing.

Turner, J. C., Oakes, P. J., Haslam, S. A., \& McGarty, C. A. (1994). Self and collective: Cognition and social context. Personality and Social Psychology Bulletin, 20(5), 454-463. https://doi.org/10.1177/01461672941050002

van Wichelen, S. (2000). The state and gender-based violence in Indonesia: A study into the May 1998 riots [Tesis tidak dipublikasikan]. Utrecht University, Netherlands.

Waddington, D., \& Moran, M. (2020). Understanding urban riots. Oxford Research Encyclopedia Of Politics. https://doi.org/10.1093/acrefore/9780190228637.013.1605 
Winarnita, M. S. (2011). The politics of commemorating the May 1998 mass rapes. Review of Indonesian and Malaysian Affairs, 45(1\&2), 133-164.

Winarnita, M. S., Chan, C., \& Butt, L. (2020). Narratives of exile twenty years on: long-term impacts of Indonesia's 1998 violence on transnational Chinese-Indonesian women. Identities, 27(2), 191-209. https://doi.org/10.1080/1070289X.2018.1537639

Winarnita, M. S., \& Setiawan, K. M. P. (2020). Commemorating gendered violence two decades on. Dalam A. D. K. McGregor \& H. Loney (Eds.), Gender, violence, and power in Indonesia: across time and space (hlm. 119-142). Routledge.

Young, J. (2011). The criminological imagination. Polity.

Zomeren, M. v., Postmes, T., \& Spears, R. (2008). Toward an integrative social identity model of collective action: A quantitative research synthesis of three socio-psychological perspectives. Psychological Bulletin, 134(4), 504-535. https://doi.org/10.1037/0033-2909.134.4.504 